\title{
Interactional straining and the neoliberal self: Learning English in the biggest English corner in China
}

\author{
S H U A N G A O \\ Department of English, University of Liverpool 19 Abercromby Square, \\ Liverpool, UK, L69 7ZG \\ sgao@liverpool.ac.uk
}

\section{A B S T R A C T}

This article proposes the term interactional straining for the strategic manipulation of interaction as grounded in neoliberal governmentality. The interactional practice was observed among adult English learners in Yangshuo, which, through mobilizing English-speaking foreigners and commodifying English, has been attracting Chinese nationals seeking to improve their English, the gate-keeping language in global workplaces in China. Based on ethnographic observations and interviews, it is shown that what appears to be naturally occurring interactions with foreigners actually involves reflexive thinking at the backstage (Goffman 1959), which is aimed at the strategic manipulation of interactional contents and/or structure so as to establish oneself as (pass for) a legitimate interlocutor. This study shows that interaction constitutes a key site where the contradictions and tensions of neoliberalism are lived out. It also argues that as reflexivity becomes a key morality under neoliberal globalization, metadiscourses provide important insights for our critique of neoliberalism. (English, language ideology, interaction, neoliberalism, work, globalization, China)*

\section{N T R O D U C T I O N}

In the famous Harvard Business Review, a recent article entitled 'Global business speaks English' begins: 'Ready or not, English is now the global language of business'. Citing exemplar cases of multinational companies from around the world, the article proposes that 'adopting a common mode of speech isn't just a good idea; it's a must... The benefits of "Englishization"... are significant' (Neeley 2012). On the other side of the globe, writing from a different linguistic background and social perspective, a commentary article published in the Chinese online news media Guānchá 'Observer' reports that English has become the most widely used language in global workplaces in China. Quoting national survey statistics, it observes that 'English is the most frequently used language in foreign companies (wàiq China], and the only language used in formal settings. 44\% of documents are written in English, 75\% of PowerPoint presentations are in English'1 (You 2013). 
These figures attest to the status of English as the language of global business communication, but their implications are far more complicated. Calling the increasing importance of English in China a form of self-imposed colonization, You (2013), a lawyer, outlines the likely disadvantages Chinese working professionals may face in cases of work-related legal disputes. Nevertheless, he continues to observe the unsettling facts that

\footnotetext{
In wàiq $\breve{l}$, many Chinese employees have unspeakable bitterness. First, when people around are all speaking in English, it is almost impossible for individual workers to insist on speaking Chinese only. Second, when fluency in English language can become an obstacle to professional advancement, you risk losing your income if you choose not to speak English. Especially when people around you are all trying hard to learn English, you also have to, unless you do not care about your future career.
}

Thus, despite potential pitfalls, there seems to be no alternative to the adoption of English in global workplaces, and such a status quo is not just a matter of company language policy. This is because English is widely accepted as the default language of business communication ('people around are all speaking in English'), and a high-stakes linguistic capital that working professionals compete for ('people around you are all trying hard to learn English'). Under this interactional regime (Blommaert, Collins, \& Slembrouck 2005), English has become a symbolic force of exclusion and stratification in global workplaces in China.

In this article, I ask how English has become a dominant language of business communication, and how the pursuit of English is grounded in the cultivation of human capital under the new work order (Gee, Hull, \& Lankshear 1996) in postsocialist China. I address these questions by looking at a group of lower middle-class ${ }^{2}$ working professionals who have decided to quit their jobs and invest in English language learning on a full-time basis in hopes of improving their competitiveness as they try to move up the English-mediated workplace hierarchy. Observational and interview data were collected during ethnographic fieldwork in 2011 in Yangshuo, a southern tourism village that since the late 1990s has been gaining increasing popularity among Chinese nationals as a place to practise spoken English (Gao 2012b). What distinguishes English learning in Yangshuo is the opportunity for people to practise English with the many foreign travelers there, hence its self-designation as the 'biggest English Corner in China' (Yangshuo Tourism Bureau 2009). By looking at the way Chinese working professionals practise English in Yangshuo, my purpose is not to evaluate the effectiveness of this learning method, nor do I seek to find out whether learning English eventually helps them achieve their professional goals. Rather, I examine the observed phenomenon of practising English with foreigners in Yangshuo as an 'activity type', that is, a 'recognized activity... whose local members are goal-defined, socially constituted, bounded' (Levinson 1979:368), in particular with regards to how such activity is embedded in the changing political economy of China, thereby contributing to the emerging research into the intersection of language and neoliberalism (Gray 2010; Park 2010a, 2013; Piller \& Cho 2013; Price 2014; Holborow 2015). 
Neoliberalism can be understood as the shifting relationship between market and state wherein the market is acclaimed as the best guidance for economic practice, and the unleashing of individual freedom and entrepreneurship in a free market the best way to achieve personal welfare (Harvey 2005:2). Neoliberalism, therefore, is not just an economic theory, but a hegemonic discourse that affects people's everyday conduct, such that individuals' entrepreneurial virtues, as opposed to systematic structures, are to be held accountable for personal success or failure (Harvey 2005:65-66). In other words, neoliberalism can be seen as the hegemonic transformation of subjectivity (Read 2009:26). This understanding of neoliberalism, or what (Ong 2007:4) calls 'neoliberalism with a small "n" ', moves beyond neoliberalism as only an economic doctrine or market ideology, and examines it as 'a technology of governing' (Ong 2007:4). Under the neoliberal regime, the ideal figure of the neoliberal self is supposed to take initiatives, make calculative choices, and exert entrepreneurship towards the cultivation of self as 'self-actualizing or self-enterprising subjects' (H. Yan 2003; Ong 2007:5; Urciuoli 2008), destabilizing the old politics of self based on communitarian solidarity and common good (Read 2009). As Thatcher most famously puts it, 'there is no such thing as society, only individual men and women... economics are the method, but the object is to change the soul' (as quoted in Harvey 2005:23). Such a conception of self has now become a new regime of truth, but its hegemony is achieved not through censorship but through unleashing personal desires, freedom, and entrepreneurship. This conforms to what Foucault (1991) calls governmentality, wherein the government of self gets internalized as a moral issue instead of passive obedience to external violence or coercion. As Ong elaborates:

following Foucault, 'governmentality' ... covers a range of practices that 'constitute, define, organize and instrumentalize the strategies that individuals in their freedom can use in dealing with each other'. Neoliberal governmentality results from the infiltration of market-driven truths and calculations. ... individuals... are then induced to self-management according to market principles of discipline, efficiency, and competitiveness. (Ong 2006:4)

The ideal figure of the neoliberal self, however, is not reproduced seamlessly in everyday life without tensions. As Harvey (2005) reminds us, while some people, social elites in particular, are more apt at and therefore benefit from such new rules of the neoliberal economy, other people may struggle with it or simply never catch up (Piller \& Cho 2013). The triumphant dominance of neoliberalism on the global scale partly depends on its rhetoric of resorting to social and moral values of wide appeal (e.g. freedom), while disguising its goals of wealth accumulation and the restoration or creation of elite power (Harvey 2005). This disjuncture is arguably the 'most essential feature' of neoliberalism (Brenner \& Theodore 2002:353). In reality, neoliberalism has created the most unequal world in recent human history (George 1999; Harvey 2005), and is differently experienced by different social groups and individuals (Ong 2006, 2007). Personal freedom therefore ends up being often constrained, rather than being expanded, not only because of class-based unequal access to social resources, but also because personal success 
tends to be narrowly evaluated in terms of human capital and its market value, in particular through the accumulation of marketable skills (Urciuoli 2008), given that neoliberalism is about the 'commodification of everything' (Harvey 2005:165).

These observations indicate that our critique of neoliberalism needs to be sensitive to social differentiation and stratification, and it is attention to people living in precarity (material, semiotic, or psychological) that enables us to most forcefully critique neoliberalism. As I show below, the majority of adult English learners in this study were lower middle class working professionals from the Pearl River Delta, a region at the forefront of China's neoliberalization process (Ong 2006); the English corner in Yangshuo, located in close proximity to the region, makes it an important site to explore the dynamics between neoliberalism and language learning. Interviews with adult language learners in Yangshuo show that what appear to be naturally occurring conversations with foreigners actually involve reflexive thinking at the backstage (Goffman 1959, 1963), which is aimed at the strategic management of interactions for the pursuit of English. The term interactional straining is proposed for such management of interaction, that is, reflexive and strategic manipulation of interactional contents and/or structure so as to establish oneself as (pass for) a legitimate interlocutor. As I argue below, this interactional practice constitutes an important venue to examine the effects of neoliberal governmentality.

This article is structured as follows. I first provide the sociohistorical context of the restructuring of the job market in China since the 1980s, and show how this has led to the valorization of English as an important part of human capital. I then introduce the research site, and show how Chinese working professionals navigate and explore English language learning opportunities in Yangshuo. The actual process of talking to foreigners turns out to be full of constraints and tensions, involving the strategic manipulation of interaction, which, as mentioned above, I characterize as interactional straining. I conclude with a discussion of the implications of the findings for our understanding of language and the political economy.

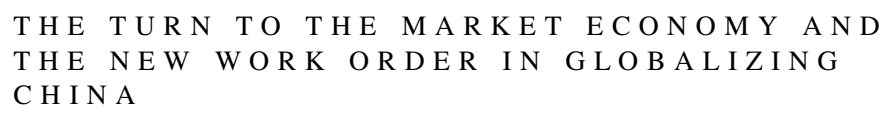

\section{Economic reform, privatization, and social stratification}

The year 1978 marked the start of China's economic reform from central planning to market socialism as Deng Xiaoping regained political power. While people had enjoyed relatively high job security under the planned economy, their lack of entrepreneurship and initiative supposedly contributed to the underperformance of many state-owned enterprises (SOE) (W. Zhang 2000). Many SOEs were then privatized, and, meanwhile, individual entrepreneurship was also encouraged to allow for the legitimate co-existence of private economic entities. During this process, the 
assignment system, wherein people's jobs were assigned via central planning as an 'iron rice bowl' (permanent job), was gradually replaced by a flexible labor market, with people being allowed for the first time to work in a position of their own choice (W. Zhang 2000; Hoffman 2007).

The privatization of SOEs resulted in massive layoffs and high job insecurity (Bian 2009:177). But Deng showed his resolution in economic reform through his famous South China Tour in 1992. The Tour was meant to further reform China through experimentally opening its economy in certain special regions (W. Zhang 2000; Ong 2006). The experiment was first introduced in coastal cities (e.g. Shanghai) and special economic zones (e.g. Shenzhen) before being implemented in other parts of China. Shanghai was transformed into the commercial center of China, whereas Shenzhen, in Guangdong Province, also quickly became one of the most developed cities in China due to its geographical proximity to Hong Kong. As regional disparities began to emerge and enlarge, an unprecedented scale of internal migration started and continues to this day as people pursue better opportunities outside their official place of residence (hùkŏu). These transformations have effects on the way people perceive their work, the job market, and also their self-identification as working professionals, pushing Chinese society towards what Deng calls a 'personal responsibility system' (Harvey 2005:168).

\section{China joining the World Trade Organization}

Concurrent with this process of economic reform is internationalization, in particular by opening China to foreign direct investment (FDI) since the 1980s. In the early phase of opening up, overseas Chinese played an important role, as their cultural and linguistic ties made them a privileged group to explore China's market (W. Zhang 2000; Harvey 2005; Q. Zhang 2005; You 2013). The financial market of China, however, was not yet fully open to the outside world, which helped exempt China from being affected as seriously as other countries during the Asian financial crisis (1997-1998) (Rofel 2007). But witnessing the contaminant consequences of neoliberal globalization on other Asian countries, China did become more aware than ever that the world has now become a global village and no country can exist in isolation, which helped accelerate its decision to join the World Trade Organization (WTO) (see Rofel 2007:ff157).

Upon its entry into the WTO in 2001, China faced the difficult work of further reforming its economy as well as opening itself up to international finances. But, run by a single-party system and an authoritarian state, China proceeded with its market reform not through political hearings or debates, but through what Rofel calls the familiar Chinese political ritual of 'educational campaign' (Rofel 2007:171), intending to change people's consciousness about the WTO and indeed globalization. Most notably, Rofel (2007) observes that, Wu Yi, one of the key 
negotiators of China's entry into the WTO and later Vice Premier of China (20032007), attempted 'the intimate articulation of economic policy and subjectivity' (Rofel 2007:173). As China finalized its WTO commitments, Wu delivered the speech below to Chinese political cadres:

You need to ensure that the masses have a basic understanding of the WTO. Push forward a change in mentality, increase a more open consciousness, create the necessary social basis... Create an environment that will keep people tied here, establish mechanisms for allowing superior talent to be distinguished and for giving free rein to people's capabilities. (Wu 2001:69, as cited in Rofel 2007:173)

As Rofel (2007:176) shows, such discourse that links political economy with the transformation of self can be seen as a classic example of neoliberal governmentality (Foucault 1991). Similarly, Ong (2007:6) observes that 'more striking than in Western contexts, in Asian milieus of development, neoliberal thinking is directed toward 'the promotion of educated and self-managing citizens who can compete in global knowledge markets'. In this historical process, we see the growth of a new generation of Chinese working professionals in the job market, who constitute the emerging middle class, as both the key players in the global economy, and yet also the most direct targets of neoliberal thinking (Hoffman 2007; Ong 2007:6).

Language is deeply embedded in this changing political economy of China. Among others, the restructuring of the job market has effects on the way people access, evaluate, and use language varieties. For example, Qing Zhang (2005) shows how in the early phase of opening up, when overseas Chinese played a prominent role, urban professionals in wàiq $\breve{~ a p p r o p r i a t e ~ t r a n s n a t i o n a l ~ C h i n e s e ~(H o n g ~}$ Kong and Taiwan) varieties to construct their yuppie identity. Such an appropriation, as Zhang (2005) convincingly shows, is largely motivated by class distinction and consumerism. In the case of English, however, as I show here, its more recent adoption in wàiq $\check{~ i s ~ n o t ~ t o ~ b e ~ e x p l a i n e d ~ o n l y ~ i n ~ t e r m s ~ o f ~ s o c i a l ~ d i s t i n c t i o n, ~ b u t ~ a l s o ~}$ as professionalism and neoliberal subjectivity. With the further globalization of China, Chinese urban working professionals are not just demonstrating the coolness of white-collar identity (Q. Zhang 2005), but facing great pressures, especially among the lower middle class, to make rational choices and practise 'self-enterprise and self-reflexivity in the face of market uncertainty' (Ong 2008:184), including quitting jobs to improve English, the language that is defining what personal success means in globalizing China.

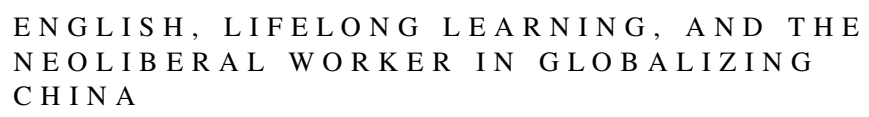

Since the 1990s, China's growing integration with the global world has made preparing personnel with knowledge of business English an urgent issue. Against this context, communicative competence in English is specified as the main objective in 
a series of national English syllabuses issued in 1992, 1993, and $1996(\mathrm{Hu}$ 2005:10-11). Two national English tests, the Cambridge Business English Certificate (BEC) test, and the China Public English Test System (PETS), with emphasis on business communication, were also introduced in 1993 and 1999 respectively to be taken mainly by working professionals (Pang, Zhou, \& Fu 2002). In 2001, right after Beijing won the bid for the 2008 Olympics, and just a few days before China officially became a member of the WTO, People's Daily, one of China's major newspapers, issued a report entitled 'More Chinese value communication skills'. As reported, Stephen E. Lucas, Professor of Communication Arts at the University of Wisconsin, arrived to lecture on 'China, globalization and public speaking' in Beijing. The participants were said to have acknowledged the need to learn 'western style communication skills'. 'As China remains the fastest-developing economic power worldwide', the article concluded, 'more Chinese people have to learn to voice their thoughts in a globally accepted way' (People's Daily 2001).

With this rising importance of English for upward mobility in both education and work, there emerges a national craze towards English. Private English language training centers started to appear and quickly expand under the market economy, catering to this increasing demand for English and making English language education a multibillion industry (US $\$ 4.7$ billion in 2010) (Bolton \& Graddol 2012:3; see also Wang 2004 and Hu \& McKay 2012:347). The privatization and industrialization of English language education makes English a commodity, further perpetuating the unequal access to English that has already become a marker of middle-class identity (Hu 2005; Gao 2012a).

Notably, the need for improving English does not stop as one finishes education in the traditional sense. In recent years, Chinese working professionals find themselves caught up in the ever increasing requirement for English, as documented in media reports (Z. Yan 2010; You 2013), though little empirical research has been done (Bolton \& Graddol 2012:7-8). In fact, the year after China joined the WTO, a society of lifelong learning (终身学习型社会) was put forward by the Communist Party of China (CPC) as an integral part of its goal to build a well-off (xiăokāng) society (China Education Daily 2013). Clearly, such objectives apply not only to institutional education per se, but also towards the cultivation of human capital as proposed by Wu Yi in 2001, that is, to 'allow superior talent to be distinguished' and 'give free rein to people's capabilities' (Wu 2001:69, as cited in Rofel 2007:173). Similar to what has been observed in Europe then, neoliberalism in China pertains to the way economics, knowledge, and learning interact (H. Yan 2003; Olssen 2006:217; Ong 2006). The cultivation of human capital through lifelong learning represents what Olssen (2006:224) calls 'internalized educational aspiration', so that essentially learners become 'the entrepreneurs of their own development'. Against this national context, English language learning has become the key site where we can observe effects of neoliberalism. 
THE FACES METHOD AND ENGLISH

LANGUAGE LEARNING IN YANGSHUO

\section{Research site and data collection}

Yangshuo is located in Guangxi Zhuang Autonomous Region in southern China. As early as 1978, Yangshuo was designated as one of the first tourist destinations open to foreigners, and has been gaining in reputation and popularity among foreign travelers because of its karst mountains and rivers (Storey, Goncharoff, \& Liou 1998:774). However, since the 1990s, with the lifting of constraints on geographical mobility among Chinese nationals, the domestic tourism market started to emerge and quickly expand (Gao 2012a). Against this background, Yangshuo, in an attempt to attract domestic travelers, started to capitalize on the availability of a large number of foreign travelers, and to promote itself as an 'English corner', that is, a public place for people to practise spoken English. Under favorable local government policies, private language schools started to be established, recruiting English-speaking foreign travelers on flexible contracts. My interviews with foreigners teaching English show that they took up teaching positions mainly to support themselves financially while travelling around Yangshuo, though they may not have had equivalent teaching experience in their home countries. This conforms to Uriely \& Reichel's (2000:270) observation that:

tourist-workers... share the tendency toward low spending as a result of their wish to experience a long-term trip despite budget restrictions. In order to finance their prolonged trip, they also tend to engage in occasional and usually short-term employment during their trips. The jobs that they take are usually not related to their education, training, or skills. ... Their involvement in these kinds of work is obviously not part of an occupational career. Yet, it is instrumental in terms of financing this touristic pursuit.

Notably, foreigners (老外) are highlighted in tourism promotional discourses as figures of linguistic authority and authenticity so as to attract English language learners (Gao 2012a; see also Seargeant 2005; Henry 2010, 2013; Park 2010b). In this process, therefore, English comes to acquire economic value, and English-speaking foreigners become moving subjects to be managed for the 'territorial concentrations of resources' (Sassen 2002:2, as cited in Hannam, Sheller, \& Urry 2006:7). Such mobilization of foreigners and commodification of English boost the local economy by attracting an increasing number of Chinese nationals. Statistics show that 'the number of the schools once reached a historical high of 48 in this small region. From 2004 to 2009, more than 50,000 people came over to learn English, along with more than 200,000 friends and relatives visiting as tourists' (Jiang 2009:59).

At the language school where I did my fieldwork, the regular students were working professionals, most from small or medium-sized transnational companies in the Pearl River Delta. Below is an extract from the website of Samuel Language School, ${ }^{3}$ provided in the Q \& A session as a reply to 'Who is this school for?'. 
Harry, with a bachelor's degree, obtained his Band- 6 certificate ${ }^{4}$ in English during his college years. He worked as a financial manager in a company in Shenzhen... After seeing our school on the internet, he immediately added our website to his Favorites toolbar, and asked for leave of one month to study here. But he felt that he had not enjoyed himself enough here for staying just one month, so he simply quitted his high-salary job and studied for another two months.

When people who did not understand asked why he quit such a good job, he explained like this: (i) You have all the chances in the world to make money, but there are not many chances like having a good time studying here. You can not only improve your English, but also relax among the nice scenery of rivers and mountains. (ii) The expenditure for learning three months here costs even less than learning for just one month in Guangzhou, Shenzhen, or Zhuhai. The price is so good. (iii) The learning environment here is unique, and cannot be found in other places in China. Every night you can chat with foreigners over beer. Where else can you find such feelings? ${ }^{5}$

As we see below, actual language learning in Yangshuo is not as glorious as this sketch might suggest, but even so, the large number of foreigners and relatively low cost of learning have made Yangshuo an attractive and affordable place among lower middle-class working professionals seeking to improve English.

Samuel Language School, established in 2001, was one of the oldest and most popular schools in Yangshuo, with its motto being 'success in English, success in life'. According to news reports at the school's website, during his visit to Samuel Language School in March 2012, Xin Changxing, vice minister of the Chinese Ministry of Human Resources and Social Security, applauded the students' spirits of self-development after learning that many had come over to learn English after quitting their jobs, wishing them success in achieving their English dreams.

During my fieldwork in 2011, I carried out observations and interviews. My original plan was to audio record interactions between students and foreigners, but such interactions turned out to be too opportunistic to be properly recordeda student would talk to a random foreigner at a random time/place, which meant it was impractical for me to obtain participants' consent beforehand and record the conversations. I therefore carried out some on-site observations, but mostly relied on interviews with foreigners and students. These interviews, as I show later, provide accounts of how students made sense of their interactions with foreigners, which cannot be obtained by looking at recorded interactions alone. In other words, these interviews produce meta-discourses of interaction that turn out to be crucial in revealing the language ideologies - 'conceptions of ... the nature and purpose of communication and of communicative behavior' (Silverstein 1987:1-2, as cited in Woolard 1992:235) - underlying interactions between students and foreigners.

Altogether, I interviewed twenty-four adult students and eight 'local foreigners' (本地老外 běndì lăowài), a local term referring to foreigners living in Yangshuo. I asked students questions about their reasons for learning English, and their English 
learning activities inside and outside of school. Interviews were conducted in English, as required by the School, but before one-to-one interviews with students, I always told them to feel free to use Chinese if they preferred. Generally speaking, they were working professionals (aged from twenty-two to forty, average age 27.8) who used to hold lower-rank positions in small or medium-sized enterprises dealing with international trade. They may or may not have college degrees and none of them had studied abroad. But all of them ${ }^{6}$ had the similar experience of having quit, or intending to change, jobs before coming to Yangshuo, hoping that better English would later help them find better jobs. Seven of the eight local foreigners I interviewed were working at Samuel's as language teachers while traveling in Yangshuo, with the other one being a former English teacher who was running a coffee shop at the time of the interview. I asked them about their life and work in Yangshuo and their experience of interacting with Chinese people in English. I also made random observations of interactions between foreigners and adult students.

\section{The adult English language learners}

With years of working experience, the working professionals' decision to learn English represents a calculated choice and reflexive decision in relation to the dynamism of the global economy and the labor market (Ong 2007:4-5). For example, in (1) Jon told me why he quit his job to learn English.

(1) Jon, thirty-six years old, used to be a salesperson in Guangdong, had been studying in Yangshuo for seven months

because it's not easy to get more order in the market now... because it is difficult time for many companies. Maybe in this financial crisis, many companies meet, meet, er, er, this difficulty, so so I think I must I have to learn something to improve myself, and looking for another job.

Such discourse of increasing one's employability through English learning was also echoed by other participants, as they looked forward to 'the promise of English' (Park 2011), that is, a better job with higher pay.

(2) Zed, twenty-five years old, car-parts production supervisor, worked in Hunan, had been studying in Yangshuo for more than one year

actually that's why I quitted the job. I didn't pass the exam for the job promotion. I was the supervisor in the department, and I had to pass the exam to become the manager. I didn't pass the exam. [The exam] it's about knowledge, and relationship, and professional skills, and also English. Because they used English for the interview, every part I did a good job, but interview it's very very bad. ... They have three men [examiners], they asked me many questions about cars, my hobbies, and something. I didn't answer [well], because I didn't know their meanings. It was not very difficult questions. 
(3) Tina, twenty-two years old, salesperson working in Guangdong, had been studying in Yangshuo for two months

I want to change another job. They want PETS $-4^{7}$. I have no choice... I still want to do international business. [But] I want to be a manager, not just a staff. I don't always be a staff or worker. If I learn English well, I get promotion... I have to improve myself.

As Tina and Zed explained, English has become an important part of human capital and a gate-keeping language in global workplaces in China, and their pursuit of English is largely motivated by the need, if not imperative ("I have no choice"), for self-improvement. However, English not only supposedly helps increase the chance of upward mobility; good English has also become almost iconic (Irvine \& Gal 2000) of professionalism, the lack of which could even become a target of contempt. For instance, Amy, with almost ten years of working experience, was already a manager in charge of her company's business transactions with about nineteen countries. She nevertheless quit her job, not just because of her incompetence in English, but also because this had led to disrespect from her employees. Below is what she said when I asked her why she wanted to learn English.

(4) Amy, thirty years old, manager of a company in Guangdong, had been studying in Yangshuo for about ten months

Because I want to be 名正言顺的经理 [a manager in the real sense of the word]. No complaints from my employees. Sometimes my assistants would compare with me in a quite sensational way. Just like, why you don't know English and you can get higher salary than us? And if I let them do the translation, 有时候假装没听到, 尤其是 pay day [they sometimes pretended they didn't hear me, especially when it was the pay day]. I can feel that. Sometimes I asked them to do some extra work, they refused me. They said "I don't like to work overtime, because my salary is too low, my position is low, you can do it, don't ask us".

For Amy, her weaker English language competence, as compared to that of her subordinates, is not simply a practical problem that interferes with her job performance as a manager; it is also an issue of professionalism, which ultimately leads her to question whether she is "a manager in the real sense of the word". Through improving English, she said, "[I hope to] do my future work well without translators. If I have a high position, I also need an assistant, but not for translating". Therefore, while having an administrative assistant testifies to Amy's high professional position as a manager, having a language assistant, or translator, only undermines her professionalism. In this way, the English language is naturalized as an indispensable component of the ideal professional identity, and 
investment in English internalized as a moral issue. A good command of English not only helps improve work efficiency but, more importantly, authenticates a professional identity through the demonstration of English as proof of legitimacy, credibility and authority (Wee 2008:261-64). Amy's bold move to quit her job and invest time and money in learning English is precisely a way of realigning herself with this neoliberal ideal, as it positions her as willingly taking risks to improve her English rather than remain secluded in her already-achieved position as a manager. It is in this context that Chinese working professionals in the present research started their quest for English.

\section{The FACES method}

English learning in Yangshuo is based on a folk language learning method-the 'FACES successful English learning method', developed by Zhang, a former tour guide who spearheaded the English education industry in Yangshuo back in the 1990s. Despite having no academic background in English language education at all, Zhang managed to obtain support from the local government due to the great contribution his entrepreneurial initiative could make to the local economy. Zhang elaborated on the FACES method during an interview with a local radio station:

My method is to ignore grammatical concepts like tense and others completely, and start straightaway from having conversations with foreigners. ... We should think of English not as knowledge, but as an everyday skill — just like we don't really need to know about physics to learn to ride a bike. ... We should not care so much about miànzi [face] - just open your mouth even if you could make mistakes. So our FACES learning method, to say it in English, is I enjoy losing face in order to learning my English way [sic].

Each character, as Zhang further elaborated, stands for one submethod of learning English:

Face to face with foreigners

Ask and answer

Change and change — change one sentence to ten sentences; change short sentences to longer sentences

English to English

Swimming successfully

English here is advocated as a 'skill' as opposed to 'knowledge'. This discourse of 'skill', abbreviated as FACES, makes it convenient to technologize and commodify English (Block 2002; Kramsch 2005) by erasing the complex social embeddedness of interactions (Gaudio 2003), which in turn exacerbates potential tensions in actual interaction, as we see below. Indeed, at the school, there are no explicit guidelines as to how exactly students should approach foreigners and how to manage these conversations. Nevertheless, all twenty-four students, like the exemplary student Harry promoted on the school's website, told me they 
would proactively seek opportunities to talk with foreigners. Philip, an English language teacher from Canada, also observes about English learning here:

if someone really wants to learn English, you have all the chance in the world to practice English, you know. You can go to a bar, you know, to chat with different kinds of traveler every day, and at the school they can speak English eight hours a day, even when outside the class, they speak English with us, we speak English with them. So er it's a big opportunity for them.

While the absence of specific regulations seem to empower language learners ('you have all the chance in the world to practice English'), it in reality only intensifies the degree of self-control ('if someone really wants to') — a manifestation of the key paradox of neoliberal governmentality. In other words, the FACES method works by capitalizing on people's desires (Read 2009) for authentic English and interaction, as opposed to merely sanctioning or regulating people's actual learning behavior. The ideal learner therefore is supposed to actively seek learning opportunities through self-governance (Olssen 2006). How exactly learners conceptualize and manage interactions with foreigners therefore becomes a key site where we can observe the effects of neoliberal governmentality.

TALKING TO FOREIGNERS: A PRECARIOU S G E N R E

As we have seen, English language learning in Yangshuo involves maximizing one's opportunity to talk with foreigners. However, contrary to the school's advertisement that such opportunities are abundant, anywhere and anytime, the actual process of talking to foreigners was constrained. In this section, I first show how talking to foreigners may backfire, and then show how students strategically navigate among foreigners to establish themselves as legitimate interlocutors for the purpose of language learning.

\section{Intrusive exploitation of interaction: Foreigners' perspectives}

Based on my interviews and observations, there are mainly three public places in Yangshuo where foreigners tend to predominate, and also where interactions between foreigners and students could be frequently observed: school areas, business streets, and bars (or similar establishments).

Peter came from the US and had worked at Samuel's for the longest period of time (about two years) among all of the teachers I knew. He explained to me at length about the popularity of Yangshuo and how talking with many foreigners here was like 'immersion learning'. Nevertheless, when asked about his own experience of talking to people on the street, Peter framed it in a different way:

Well, usually I don't have time, right, and I would say I'm sorry but I'm going somewhere, sorry I can't. ... But, to be honest, I don't think I'm a very outgoing kind of person. ... I'm usually not really excited. ... I don't usually have conversations like this, with er people who want to practise English. 
Here Peter first said he could not have such conversations because he was usually quite busy, which turned out to be a polite excuse when he added that a more honest reason is that he was not outgoing. Such self-exclusion as a potential interlocutor with English learners, however, was not just a matter of temperament (outgoing or not), as Peter himself claimed. As I found out, since foreigners are constantly approached for a talk in English, many of them, like Peter, have learnt to avoid such conversations which, according to their own account, tended to be repetitive, simple, and boring.

One afternoon, I was sitting on a bench outside the school building, having a small chat with a couple of teachers. Several students then walked out from the building and eagerly 'helloed' to join the conversation. "Not a moment's break", Philip whispered helplessly to another teacher, Sam. When the students came over and sat down, one of them asked Sam with not-so-fluent English, "Are you a new teacher? Because I haven't seen you before". "I've been here for about one week", he replied, "and you?" "I am an old student. I have been here for for three, three, three weeks". Obviously, she was searching for the word week. "I thought you were going to say three month"; he looked at Philip and they grinned to each other (field note, 8 July 2011). Seeing this, I was reminded of the interview I had with Sam several days earlier (4 July 2011). Reflecting on his experience of being approached for a talk in English, he said:

Sometimes talking to a person with low English competence can be stressful. You have to change your mind a little bit. You know, you have to think slower, and talk slower, and listen very carefully, and it's like teaching, you know. Sometimes you feel like if you get paid.

As he finished, he looked at me with an awkward smile. On the one hand, he did teach at the language school and got paid for his work. Yet, on the other hand, being constantly approached for a talk in English made him feel unreasonably exploited for his linguistic capital. Adjusting to the interlocutor's pace of talk ("think slower, talk slower"), being more attentive ("listen very carefully"), and spending greater efforts to figure out meanings of interaction ("change your mind a little bit"), these otherwise unnecessary accommodations seemed like doing extra work ("sometimes you feel like if you get paid"). Indeed, that day immediately after my interview with Peter, I asked whether he was going upstairs to a social event organized by the school. "Yes, I will", he replied. "You know", he then added, "I wanted to start our interview earlier because they [the school] just told me this afternoon, they want me to be the judge of the speech competition [the theme of that day's event]. I definitely wouldn't go if they hadn't asked me" (field note, 14 July 2011).

The school area is not the only place where students would seek out learning opportunities, however. Business streets and bars are actually more popular among students. In the extract below, Steve, from Ireland, raised the issue of always 'bumping into' students at bars: 
Of course, you are always, I mean, you gonna talk to people [at bars], and chances are that some of them are going to be students... Er, yeah, that's fine maybe. I mean... you bumped into them, or after school you see them there. ... I've talked to so many. ... maybe they've got very little English, or maybe they are just repeating themselves, of course, that's boring. I don't want to, it's now my social time. I have got no time teaching them English, so people like them, you know, I'll just finish the conversation, and talk to my friends or someone else.

Here, Steve explained that while there were occasions wherein "you can have a laugh you can have a joke", he also had talked to so many who had "very little English and kept repeating themselves". In such situations, he would thus have to try to exit from the conversations to safeguard his own social time.

But basically any place popular among foreigners tends to attract students. Kay was from South Africa. Like other local foreigners, he took up a job as an English teacher when he first arrived, but now he was running his own coffee shop. He said he had been stopped on the street for a talk in English so many times that he had learnt to avoid such "attempts to create interactions" that might be full of repetitive simple questions (Where are you from? Do you like China? How many cities have you been to in China? How many countries have you been to?). But there were also other concerns for him. Since he was running the coffee shop, there were also regular Chinese customers who would come and speak to him "just as a foreigner"; some even offered to work for him for free, as he told me below.

Generally they work here more to practice their English than to earn money. A lot of, a lot of students in Yangshuo work at, work at bars, work at restaurants because they just want to be in a place where people do speak English. They want to be here because I always speak English, because customers speak English. It's good, it's just practice for their English.

While free labor seemed like a good idea, Kay said this actually didn't work well because "they only want to do the nice work, they don't want to do the bad work. They don't want to wash the cups. They only want to make the coffees, and serve the customers".

As we have seen, foreigners were not always ready to talk with students, and would try to find ways to avoid such interactions. Talking to foreigners, therefore, would not happen as easily and conveniently as the FACES method prescribes and promises. Indeed, conversations never occur naturally but have constraints - the social situatedness and embeddedness of interactions as well as the necessary language competence required mean that there are always minimum conditions to be met for interactions to occur in the first place (see Gaudio 2003 for details; Goffman 1959). Successfully managing such conditions, therefore, could be vital for students to have actual access to authentic English and interaction. As already mentioned, however, the technologization of English as a 'skill' meant that knowledge of English and communication was discarded as irrelevant and not taught at schools. The adult students would thus have to find their own ways of approaching and talking to foreigners. As we see below, the students did not complain about the insufficient institutional support or the false promise of the FACES method. Rather, they became proactive learners who were managers of their own 
self-development (Olssen 2006): they showed their initiative, reflected upon the difficulties, and internalized such constraints as problems to be tackled on their own.

\section{Excitements, frustrations, and strategies: Students' perspectives}

In stark contrast to foreigners who may well dismiss such interactions as simple and boring, adult students told me how COMPLEX talking to foreigners can actually be for them - there were moments of frustration as well as excitement, and they would have to actively seek out strategies to preempt and mitigate potential tensions in interaction.

Mary had studied at Samuel's for about six months and described talking to foreigners as both nervous and exciting. She told me she was often nervous about not being able to express herself fluently in English ("just one word, one word, very slowly"), but was excited to have found an Australian friend with whom she was still in touch via Skype. Hearing this, I congratulated her on having found a friend with whom to practise English, but she responded with some frustration, as shown in (5).

(5) Mary, twenty-seven years old, salesperson and human resource officer working in Guangdong, had been studying in Yangshuo for six months

but sometimes I can't find the topic to talk, half an hour, and don't know how to continue.

[And there're] many times because they know we want to practice our English, so they go away.

Here, Mary hoped to be able to carry out longer conversations, and identified the problem as not being able to find enough topics. Also, she revealed that she might not be taken as a legitimate interlocutor because of her weak competence in English ("they know we want to practise our English, so they go away"). Similarly, another student Tina, a salesperson from Guangdong, told me that because she did not always know what to talk about, "they [foreigners] will feel very boring, and go away... I think it's very embarrassing, because we can't communicate with them, oh my God, what a pity, because we want so much to talk with them".

Here, we see that adult students were aware that they might come across as nuisances to foreigners ("they will feel very boring, and go away"). But they did not take the problems and difficulties as deriving from the false promise of the FACES method; instead they blamed themselves for not always being able to initiate or sustain conversations ("it's very embarrassing", "what a pity") and yet still showed their perseverance. In order to be able to speak with foreigners, they tried to overcome their nervousness, and identify possible reasons for being ignored. In other words, students internalized the interactional tensions and constraints that 
have been exacerbated by the neoliberal enterprise of language commodification in Yangshuo, and at the same time were persistent and proactive in finding ways to mitigate such tensions so as to pass for legitimate interlocutors - a key manifestation of the dynamic relationship between neoliberalism and active learning (Olssen 2006). For example, Lora had come up with a seemingly passive way to improve her English, as she told me below.

(6) Lora, twenty-four years old, logistics worker in Guangdong, planning to be a salesperson, had been studying in Yangshuo for four months

When I went [name] bar, I just sat there quietly and listen to others, classmate. Said nothing. I didn't say anything. ... even though I can't speak, but I can listen, I believe several times later you can speak and your listening will be better.

For Lora, being silent does not mean being uninterested. Indeed, if we rely on recordings of interactions alone, people like Lora may well be left out of the analysis because she had no voice. Nevertheless, as she explained, not talking at all does not mean relinquishing the opportunity to improve one's English; rather, it is a self-initiated strategy based on her reflexive understanding of learning (listening first, speaking later), so that ultimately one can speak out. Another student Carl told me how he and his friends managed to find the 'right' foreigners to talk with.

(7) Carl, twenty-eight years old, business owner from Guangdong, had been studying in Yangshuo for two months

I think foreigners em like beer, er he he usually oftenly sit in bar, er only drink beer...

I usually go to bar, conversation with foreigner... I came with my friends, four or three together... if I I only talk with foreigner, er, ((laughter)) I I speak a little time, I talked a little time 只能说一会, 然后就没什么说的了, 一般是 $3 、 4$ 个人一起, 这个不会那个说一下, 这样会时间长一点吧, 如果我一个人 在那跟他说的话, 说两句, 不知道说哪里去((laughter)) [I can only speak for a little while, and then have nothing to say. So usually we three or four people go together. If one person doesn't know what to say, then another person can try to say something. This way, we can talk for a longer time. If I were there alone talking with him, maybe after two sentences, I don't know what to say next ((laughter))] ... If many people together, 我不会过去 [I won't go ], if em, he only sit one there, em maybe ((laughter)) talk with foreigner.

Like many other students, Carl went to places popular among foreigners (bars), but he also opted for the strategy of finding foreigners sitting alone, who tended to be more approachable than those hanging out with friends. And he would go together with many Chinese friends so that there was always someone to fill in otherwise embarrassing silence. These strategies showed that Carl took the initiative and came up with strategies to turn potentially boring and fallible conversations into 
successful and more interesting ones. Another student, Lucy, planned to work in Yangshuo after finishing her study at the school.

(8) Lucy, twenty-eight years old, housewife, planning to look for a job, had been studying in Yangshuo for five months

after I study here, maybe I will find a part-time job here at some beer bar, about one month or two months, just to practice my oral English, and then go back to my home, find a good job... because you know... the foreigner customer want to buy something, you can communicate with them.

In the above excerpts, we see that students were eager to practise English but may have difficulty sustaining or even starting conversations. However, they were not easily deterred by these difficulties, nor did they complain about the FACES method. Instead, despite these difficulties and constraints, the students internalized these problems as something to be worked out on their own and tried to adopt varied strategies to create interactional opportunities and/or manipulate potential interactional structures, for example, by choosing the place of interaction (going to bars and shops popular among foreigners), purposefully selecting the participants and managing the topics of interaction (multiple people engaging in conversations with solo travelers), and designing one's roles during interaction (being a quiet listener, or working at a local shop). Through using these tactics based on their own reflexive thinking, they exemplify the image of an ideal neoliberal self (Foucault 1991) who, instead of passively relying on external support, shows self-discipline, internalizes constraints upon themselves, and exhibits reflexivity and calculative thinking to make an unfavorable learning environment work for their own purpose.

Talking to foreigners, therefore, turns out to be a precarious genre. The legitimacy of such interactions needs to be constantly negotiated, established, and maintained. In order to practise English, students had to carefully manage the accessibility of foreigners, exploit opportunities amid constraints, and skillfully sustain the conversation, so as to preempt possible avoidance. This informal way of learning English differs from English learning within formal educational institutions in China, wherein learning tends to be exam-oriented and the learning process subjected to regimented procedures and guidelines (Pan \& Block 2011; Peréz-Milans 2013). Learning English in Yangshuo corresponds more to the model of a proactive and self-responsible learner, for whom the neoliberal logic of autonomy, selfimprovement and self-governance is incorporated into their everyday learning process (Olssen 2006).

It is worth noting that such interaction derives not from crosstalk, that is, misunderstanding or breakdown in cross-cultural communication (c.f. Gumperz, Jupp, \& Roberts 1981), but from technologization and commodification of English that erases the social embeddedness of interactions and thereby exacerbates potential interactional constraints and tensions as students pursue the valuable linguistic capital 
of English. Students are caught up in this neoliberal enterprise, and have to constantly reflect on potential interactions, including what topic might be relevant (e.g. extract (5)), how the conversation should proceed (e.g. extract (7)), as well as overcoming anxieties (e.g. extract (5)). What appears to be naturally occurring conversations with foreigners therefore involves reflexive thinking at the backstage (Goffman 1959, 1963). As mentioned in the introduction, the term interactional straining is proposed for such manipulation of interaction, defined earlier as the reflexive and strategic manipulation of interactional contents and/or structure so as to establish oneself as (pass for) a legitimate interlocutor. Interactional straining, as documented in this study, provides a key site to observe the dynamic relationships between language and neoliberalism as it is embedded in the active and yet contentious pursuit of linguistic capital and the cultivation of human capital under the neoliberal regime.

Specifically, interactional straining involves both subjective and semiotic processes of managing conversations. On the semiotic level, it can be understood as a deliberative interactional practice based on a particular language ideology, that is, 'conceptions of... the nature and purpose of communication and of communicative behavior as an enactment of a collective order' (Silverstein 1987:1-2, as cited in Woolard 1992:235), the collective order here being neoliberal governmentality. Without explicit instructions or guidelines, the adult students in the present study showed their initiative in language learning and self-development through actively designing and manipulating interactional contents and structure. On the subjective level, it also indicates that there are mixed emotions and anxieties as students tried to align themselves with the role of a legitimate interlocutor, instead of being merely a learner of English. Neoliberalism shapes, not determines, subjectivitythe ideal image of the neoliberal self is not seamlessly reproduced without struggles. There are always tensions in negotiating or manipulating potential interactions, regardless of whether interaction actually occurs (ignored or not), how it proceeds (boring or not), and how it ends (sustained or not). As the lower middle-class working professionals align themselves with the ideal image of the neoliberal self, they are caught up in a precarious process of strategically exploring interactional opportunities amid constraints, and skillfully sustaining conversations so as to become legitimate interlocutors for the purpose of language learning.

CONCLUSION AND D ISCUSSION: B E Y ON D

IN TER C U L T UR A L COMMUNICATION

In her seminal article 'When talk isn't cheap: Language and political economy', Irvine (1989) argues for the importance of moving beyond the sociocultural to also include political economy in deepening our understanding of the complex and multiple functionalities of language in society. While an increasing number of studies have addressed this issue, political economy remains a 'gaping hole' in much existing research (Block, Gray, \& Holborow 2012:4). Neoliberal 
globalization not only involves the reconceptualization of language as commodity (Heller 2003), but also affects the way we carry out everyday interactions (Gee et al. 1996; Cameron 2000). In particular, careful attention needs to be paid to the sociopolitical embeddedness of interactions due to the tendency to naturalize interactions in both popular and academic discourses (Gaudio 2003). When it comes to users of English as a second/foreign language, however, these issues have been rarely explored (though see Block 2002 and Kramsch 2005). The notion of culture tends to be drawn upon to both problematize and explain interactions, for example, miscommunication, misunderstanding, or discrimination. In other words, much research still has not moved beyond what Gumperz calls 'crosstalk' (Gumperz et al. 1981; Gumperz 2006; Young 2006). While the issue of culture remains relevant, it may also disguise some of the underlying mechanism through which language and political economy intersects (Piller 2011; Park 2013; see also Harvey 2005:39-40). Besides, such culture-based explanations tend to reproduce a stereotypical image of users of English as a second/foreign language who are linguistically incompetent and often fail to pick up the subtleties of conversational meanings. The present study, through looking at Chinese people practising English with foreigners in Yangshuo, shows that tensions in interaction may also be grounded in the materiality of political economy.

Specifically, I have shown that neoliberalism shapes the way people conduct their everyday lives - they are supposed to take initiatives based on their judgment and evaluation of the market so as to achieve self-development and maintain competitiveness. The English language represents one important terrain wherein Chinese working professionals find themselves compelled to invest as they aspire to move up the workplace hierarchy. Through their very decision to quit jobs, invest in English, and approach foreigners to talk with, the participants in the present study provide an illuminating case of the cultivation of human capital: 'The saving of labor time is equal to an increase in free time, i.e. time for the full development of the individual... the production of fixed capital, this fixed capital being man himself' (Marx 1973:712, as cited in Read 2009:33). Most importantly, I have shown that the commodification of English as a skill in Yangshuo erases the social embeddedness of interactions, which in turn exacerbates potential constraints and tensions in interaction, such that talking to foreigners becomes a precarious genre. Caught up in this neoliberal machine, the working professionals did not complain about the false promise of the FACES method or simply give up; instead, they aligned with the ideal image of the neoliberal self by internalizing these constraints upon themselves, and trying to figure out the sources of potential tensions in interactions, so as to preempt problems and establish their legitimacy as interlocutors. In other words, unlike the image promoted on the school's website wherein students happily approach foreigners for a talk over beer, there are mixed emotions and anxieties in this contentious process of pursuing English. The precarity of these interactions means the legitimacy of students' roles as interlocutors needs to be constantly negotiated, established, and maintained. Metadiscourses of interaction 
reveal the neoliberal grounding of these seemingly trivial interactions and interactional attempts.

Such interactional precarity also reflects the relatively precarious and less privileged socioeconomic backgrounds of these English learners. Compared with studying abroad or receiving solid education at more expensive English language schools in big cities in China, Yangshuo may not provide as favorable a learning environment, but for lower middle-class professionals in the present study, Yangshuo probably represents the best choice they could afford in terms of time and money as they seek authentic English, the gate-keeping language that defines their future career. In this sense, they are helplessly caught up in the whole neoliberal enterprise of technologizing and commodifying English as a skill in Yangshuo. While it is difficult to conclude from this study whether the English they learnt in Yangshuo will indeed enable them to achieve their desired goals later, we can argue that their proactive pursuit of English at least constitutes an attempt, if not an imperative, to seek self-development and stay competitive. The semiotics and subjectivities involved in interactional straining are therefore embedded in the valorization and commodification of English, the new work order, the politics of self, and new forms of social stratification and exclusion in globalizing China. It is through looking at the precarity of their everyday pursuit of English that we start to reveal the contradictions, tensions, and struggles involved in the cultivation of human capital under neoliberal globalization. 


\title{
A P P E N D IX: TR A N S C R IP TION C ONVENTIONS
}

\author{
((laughter)) laughter \\ ... omitted texts \\ [italicized] author's translation from Chinese \\ [ ] author's comments
}

\section{N O T E S}

*I would like to thank Jenny Cheshire and two anonymous reviewers for their constructive criticism and valuable suggestions. I also thank Joseph Sung-Yul Park, Lionel Wee, Marnie Holborow, Claire Kramsch, John Gray, Jan Blommaert, and Adrienne Lo for their helpful comments at various points of this project. Special thanks to Ben Rampton for meticulously reading earlier drafts and inspiring me with many discussions. Earlier versions of the paper were presented at the University of Hong Kong (2014) and Tilburg University (2015). I am grateful to have had the opportunities to present my work and receive helpful feedback from the audiences. All errors are my own.

${ }^{1}$ All excerpts from Chinese sources are translated by the author, unless otherwise stated.

${ }^{2}$ Lower-rank working professionals (e.g. a salesperson) are generally categorized as lower middleclass in China. See Goodman (2014) for details.

${ }^{3}$ All personal and institutional names are pseudonyms. English pseudonyms were used for Chinese working professionals in accordance with the general practice at Samuel's where each student adopted an English name.

${ }^{4}$ College English Test, Band 6, which is a national English language test for college students.

${ }^{5}$ For the sake of anonymity, URL links to the school's websites are not provided throughout the article.

${ }^{6}$ The only exception was Lucy. She was learning English to prepare herself for the job market after several years of being a housewife.

${ }^{7}$ There are five levels of PETS (the Public English Testing System), from level 1, the most basic, to level 5, the most advanced.

\section{R E F E R E N C E S}

Bian, Yanjie (2009). Urban occupational mobility and employment institutions: Hierarchy, market, and networks in a mixed system. In Deborah Davis \& Feng Wang (eds.), Creating wealth and poverty in post-socialist China, 172-92. Stanford, CA: Stanford University Press.

Block, David (2002). 'McCommunication': A problem in the frame for SLA. In David Block \& Deborah Cameron (eds), Globalization and language teaching, 117-33. London: Routledge.

_ ; John Gray; \& Marnie Holborow (2012). Neoliberalism and applied linguistics. New York: Routledge.

Blommaert, Jan; James Collins; \& Stef Slembrouck (2005). Polycentricity and interactional regimes in 'global neighborhoods'. Ethnography 6(2):205-35.

Bolton, Kingsley, \& David Graddol (2012). English in China today. English Today 28(3):3-9.

Brenner, Neil, \& Nik Theodore (2002). Cities and the geographies of 'actually existing neoliberalism'. Antipode 34(3):349-79.

Cameron, Deborah (2000). Good to talk? Living and working in a communication culture. London: SAGE.

China Education Daily (2013). How to promote lifelong learning. Online: http://theory.gmw.cn/201309/20/content_8958322.htm; accessed August 20, 2014. 


\section{INTERACTIONAL STRAINING AND THE NEOLIBERAL SELF}

Foucault, Michel (1991). Governmentality. In Graham Burchell, Colin Gordon, \& Pete Miller (eds.), The Foucault effect: Studies in governmentality, 87-104. Hemel Hempstead: Harvester Wheatsheaf.

Gao, Shuang (2012a). Commodification of place, consumption of identity: The sociolinguistic construction of a 'global village' in rural China. Journal of Sociolinguistics 16(3):336-57.

(2012b). The biggest English corner in China. English Today 28(3):34-39.

Gaudio, Rudolf P. (2003). Coffeetalk: Starbucks ${ }^{\mathrm{TM}}$ and the commercialization of casual conversation. Language in Society 32:659-91.

Gee, James Paul; Glynda A. Hull; \& Colin Lankshear (1996). The new work order: Behind the language of the new capitalism. Boulder, CO: Westview Press.

George, Susan (1999). A short history of neo-liberalism. Online: http://www.globalexchange.org/resources/econ101/neoliberalismhist; accessed May 30, 2013.

Goffman, Erving (1959). The presentation of self in everyday life. London: Penguin Books.

(1963). Behavior in public places: Notes on the social organization of gatherings. New York: The Free Press.

Goodman, David (2014). Middle class China: Dreams and aspirations. Journal of Chinese Political Science 19(1):49-57.

Gray, John (2010). The branding of English and the culture of the new capitalism: Representations of the world of work in English language textbooks. Applied Linguistics 31(5):714-33.

Gumperz, John (2006). Forward to Crosstalk and culture in Sino-American communication, by Linda Wai Ling Young, xiii-xx. Cambridge: Cambridge University Press.

; Tom Jupp; \& Celia Roberts (1981). Crosstalk: A study of cross-cultural communication: Background material and notes to accompany the BBC film. Southall: National Centre for Industrial Language Training.

Hannam, Kevin; Mimi Sheller; \& John Urry (2006). Editorial: Mobilities, immobilities and moorings. Mobilities 1:1-22.

Harvey, David (2005). A brief history of neoliberalism. Oxford: Oxford University Press.

Heller, Monica (2003). Globalization, the new economy, and the commodification of language and identity. Journal of Sociolinguistics 7:473-92.

Henry, Eric Steven (2010). Interpretations of 'Chinglish': Native speakers, language learners and the enregisterment of a stigmatized code. Language in Society 39:669-88.

(2013). Emissaries of the modern: The foreign teacher in urban China. City \& Society 25 (2):216-34.

Hoffman, Lisa (2007). Post-Mao professionalism: Self-enterprise and patriotism. In Li Zhang \& Aihwa Ong (eds.), Privatizing China: Socialism from afar, 168-81. Ithaca, NY: Cornell University Press.

Holborow, Marnie (2015). Language and neoliberalism. London: Routledge.

$\mathrm{Hu}$, Guangwei (2005). English language education in China: Policies, progress and problems. Language Policy 4:5-24.

— \& Sandra Lee McKay (2012). English language education in East Asia: Some recent developments. Journal of Multilingual and Multicultural Development 33(4):345-62.

Irvine, Judith (1989). When talk isn't cheap: Language and political economy. American Ethnologist 16 (2):248-67.

— \& Susan Gal (2000). Language ideology and linguistic differentiation. In Paul V. Kroskrity (ed.), Regimes of language: Ideologies, polities, and identities, 35-84. Santa Fe, NM: School of American Research Press.

Jiang, Yufeng (2009). Showing the humanistic and natural wonders: Thoughts on the 'Yangshuo phenomenon' and the city development of Guilin. In Tiansheng Tang \& Chen Xianzhong (eds.), Scientific development of Guangxi tourism: Exploring the Yangshuo phenomenon, 198-203. Beijing: Huaxia Publishing House.

Kramsch, Claire (2005). Post 9/11: Foreign languages between knowledge and power. Applied Linguistics 26(4):545-67. 


\section{SHUANG GAO}

Levinson, Stephen (1979). Activity types and language. Linguistics 17:365-99.

Marx, Karl (1973). Grundrisse: Foundations of the critique of political economy. New York: Penguin.

Neeley, Tsedal (2012). Global business speaks English. Harvard Business Review. Online: https://hbr. org/2012/05/global-business-speaks-english/ar/1; accessed October 5, 2014.

Olssen, Mark (2006). Understanding the mechanisms of neoliberal control: Lifelong learning, flexibility and knowledge capitalism. International Journal of Lifelong Education 25(3):213-30.

Ong, Aihwa (2006). Neoliberalism as exception: Mutations in citizenship and sovereignty. Durham, NC: Duke University Press.

(2007). Neoliberalism as a mobile technology. Transactions of the Institute of British Geographers 32(1):3-8.

(2008). Self-fashioning Shanghainese: Dancing across spheres of value. In Li Zhang \& Aihwa Ong (eds.), Privatizing China: Socialism from afar, 182-96. Ithaca, NY: Cornell University Press.

Pan, Lin, \& David Block (2011). English as a 'global language' in China: An investigation into learners' and teachers' language beliefs. System 39:391-402.

Pang, Jixian; Xing Zhou; \& Zheng Fu (2002). English for international trade: China enters the WTO. World Englishes 21:201-216.

Park, Joseph Sung-Yul (2010a). Naturalization of competence and the neoliberal subject: Success stories of English language learning in the Korean conservative press. Journal of Linguistic Anthropology 20 (1):22-38.

(2010b). Images of 'good English' in the Korean conservative press: Three processes of interdiscursivity. Pragmatics and Society 1:189-208.

(2011). The promise of English: Linguistic capital and the neoliberal worker in the South Korean job market. International Journal of Bilingual Education and Bilingualism 14(4):443-55.

(2013). Metadiscursive regimes of diversity in a multinational corporation. Language in Society 42:557-77.

People's Daily (2001). More Chinese value communication skills. Online: http://english.people.com.cn/ english/200110/30/eng20011030_83476.html; accessed July 16, 2012.

Peréz-Milans, Miguel (2013). Urban schools and English language education in late modern China: A critical sociolinguistic ethnography. New York: Routledge.

Piller, Ingrid (2011). Intercultural communication: A critical introduction. Edinburgh: Edinburgh University Press.

— \& Jinhyun Cho (2013). Neoliberalism as language policy. Language in Society 42(1):23-44.

Price, Gareth (2014). English for all? Neoliberalism, globalization, and language policy in Taiwan. Language in Society 43:567-89.

Read, Jason (2009). A genealogy of homo-economicus: Neoliberalism and the production of subjectivity. Foucault Studies 6:25-36.

Rofel, Lisa (2007). Desiring China: Experiments in neoliberalism, sexuality, and public culture. Durham, NC: Duke University Press.

Sassen, Saskia (2002). Locating cities on global circuits. In Saskia Sassen (ed.), Global networks, linked cities, 1-36. London: Routledge.

Seargeant, Philip (2005). 'More English than England itself': The simulation of authenticity in foreign language practice in Japan. International Journal of Applied Linguistics 15(3):326-45.

Silverstein, Michael (1987). Monoglot 'standard' in America. (Working papers and proceedings of the Center for Psychosocial Studies 13.) Chicago: Center for Psychosocial Studies.

Storey, Robert; Nicko Goncharoff; \& Caroline Liou (1998). Lonely Planet China: China, a travel survival kit. 6th edn. Footscray: Lonely Planet Publications.

Urciuoli, Bonnie (2008). Skills and selves in the new workplace. American Ethnologist 35(2):211-28.

Uriely, Natan, \& Arie Reichel (2000). Working tourists and their attitudes to hosts. Annals of Tourism Research 27(2):267-83. 


\section{INTERACTIONAL STRAINING AND THE NEOLIBERAL SELF}

Wang, Labao (2004). When English becomes big business. In Timothy Weiss \& Kwok-kan Tam (eds.), English and globalization: Perspectives from Hong Kong and mainland China, 149-68. Hong Kong: Chinese University Press.

Wee, Lionel (2008). The technologization of discourse and authenticity in English language teaching. International Journal of Applied Linguistics 18(3):256-73.

Woolard, Kathryn (1992). Language ideology: Issues and approaches. Pragmatics 2(3):235-49.

$\mathrm{Wu}, \mathrm{Yi}$ (2001). Base ourselves on a new starting point, shoulder a new mission: Opening a new phase in the development of foreign economic trade. Chinese Foreign Economic Trade Yearbook, 64-70. Beijing: China Foreign Economic and Trade Publishing House.

Yan, Hairong (2003). Neoliberal governmentality and neohumanism: Organizing suzhi/value flow through labor recruitment. Cultural Anthropology 18(4):493-523.

Yan, Zhiping (2010). Language use in wàiqŭ in Shanghai. Online: http://sspress.cass.cn/news/12914. htm; accessed September 3, 2014.

Yangshuo Tourism Bureau (2009). Educational tourism. Online: http://www.yangshuotour.com/yangshuolvyou/xiuxueyou/2009/1226/620.html; accessed November 8, 2010.

You, Tianlong (2013). Speaking English in wàiqu: A Chinese national characteristic. Online: http://www. guancha.cn/YouTianLong/2013_06_07_149717.shtml; accessed September 2, 2014.

Young, Linda Wai Ling (2006). Crosstalk and culture in Sino-American communication. Cambridge: Cambridge University Press.

Zhang, Qing (2005). A Chinese yuppie in Beijing: Phonological variation and the construction of a new professional identity. Language in Society 34:431-66.

Zhang, Weiwei (2000). Transforming China: Economic reform and its political implications. Houndmills: Palgrave.

(Received 8 January 2015; revision received 11 October 2015; accepted 22 November 2015; final revision received 2 February 2016) 